http://dx.doi.org/10.4314/gjl.v6i3.4

\title{
NOUN CLASSIFICATION IN ESAHIE
}

\author{
Obed Nii Broohm
}

\begin{abstract}
This paper offers a description of the nominal class system in Esahie (CentralTano, Kwa, Niger-Congo). It contends that, though the noun class system of Esahie per se is morpho-syntactically vestigial, hence differing from other African languages (e.g. most Bantu languages) where noun classes can be assimilated with GENDER, in Esahie, NUMBER, as a syntactic feature, triggers agreement, rendering the class system in Esahie a number-based one. On morpho-syntactic grounds, six distinctive noun form classes are established for Esahie. This paper also provides an account of how morpho-phonological information influences the noun form classes of Esahie. As argued for Akan (cf. Bodomo and Marfo 2006), morpho-phonological information is equally relevant for understanding the choice of one number affix over the other in Esahie. The present work presents yet another piece of evidence in support of the view (cf. Ameka and Dakubu 2008, Aboh and Essegbey 2010, and Güldemann and Fiedler 2017) that unlike the Ghana-TogoMountain languages, which have been attested to have a functional class system, the Central-Tano languages, to which Esahie pertains, have a relatively fairly decayed and less-conservative inflectional system. Comparing Esahie to Akan, however, data discussed in this paper seems to suggest, prima facie, that Esahie has suffered a relatively stronger deal of morpho-syntactic decay in the inflectional system of the nominal domain. Data used in this work is collected largely through elicitation from native speakers.
\end{abstract}

Keywords: Esahie, Kwa, Central-Tano noun class system, number, gender. 


\section{Introduction ${ }^{1}$}

The present work deals with noun classification in Esahie (Kwa, Niger Congo), a highly under-described Ghanaian language. It argues that though noun classes in Esahie by themselves are syntactically inactive, NUMBER, as a syntactic feature, triggers agreement to an extent, making the Esahie class (declension) system a number-based one. On morphosyntactic grounds, six distinctive noun form classes are established for Esahie. In the interest of word formation and language acquisition, respectively, this work also considers the productivity and learnability of the noun form classes posited for Esahie. Drawing inspiration from what has been argued for Akan, a sister (Central-Tano) language, in Bodomo and Marfo (2006), the present work further provides an account of how morphophonological information influences the noun (form) class system of Esahie. Finally, the paper examines the issue of whether or not class assignment is semantically-driven, showing that, unlike (some dialects of) Akan, which show an agreement system that is sensitive to the inherent conceptual and semantic (nominal) feature of ANIMACY (cf. Osam 1996), in Esahie class assignment appears to be invariably arbitrary.

Noun classification has been an area of long-standing interest in African linguistics. The works of Carstens (1991), Osam (1993), Schuh (1995), Ikoro (1996), Creissels (2000), Bodomo and Marfo (2006), Dorvlo (2008), Carstens (2008), Bobuafor (2013), Agbetsoamedo (2014), and Fiedler (2016), to mention but a few, help in appreciating how noun classification has been variously discussed among scholars of African linguistics. Heine et al. (1982) observe that two out of every three African languages have a system of noun classification, but not in the same way among languages or groups of languages.

Prototypically speaking, if nouns of a particular language can be categorized based on a system of concord and/or affixal markings triggered by the nouns, or the language is observed to have a kind of Gender(-like) system where selection of markers are determined or controlled by certain inherent features (semantic, conceptual, and/or formal) of a lexical noun (head/controller) nouns, that language may be argued to have a noun class system. What does not necessarily count as Gender is the marking on the noun itself, i.e. the prefixes or suffixes found in different languages. This marking is the noun form class, and reflects also a classification of nouns, but not Gender. Thus, in a language like Swahili, all

\footnotetext{
${ }^{1}$ The author wishes to thank the University of Verona (Italy) for sponsoring his PhD programme, and most especially Chiara Melloni, for her invaluable input, guidance, and mentorship, as $\mathrm{PhD}$ Advisor. The author also acknowledges the support of the following language consultants: George Atta Boateng, Evans A. AduGyamfi, Rexford Mensah, and Obed Ayisi. For the people of Sehwi/Sefwi, this is yours!
} 
nouns having the same marking in the singular and in the plural ( $\mathrm{m}-\mathrm{w} w \mathrm{a}$ - for example) belong to the same declension class. Here, the changes of the noun form are triggered by number and gender etc. The crucial point is that one cannot necessarily determine the Gender (agreement) system of a language by only looking at the noun form.

In this work, we consider what underpins both the noun form (declension) classes and Gender (agreement) system in Esahie. The rest of the paper is organised as follows. First, a general overview of noun classification system among African languages is given (section 2.), juxtaposing the Bantu and Ghana-Togo-Mountain (GTM) languages, on one hand, which have been argued to show a vibrant system, against the other Kwa languages, such as Akan, which show a residual system (section 2.1). I then proceed to focus on Esahie, showing how morpho-phonological information feeds into its system (section 3.), grouping nouns into classes based on similarity in number affixation (section 4.). While number agreement within the Esahie DP is discussed in section (5), the relationship between noun classes and (grammatical) Gender is interrogated (in the light of Kwa) in section (6), while conclusions are drawn in section (7).

\section{Noun Class System in African Languages}

As Schuh (1995) rightly points out, the usage of the terminology 'noun class' with respect to African languages has usually been understood in two senses. In one, it has been used to refer to "a single set of morphological concords which may show up as affixes on noun stems, affixes on modifiers, and pronominal referents to nouns", whilst in the other, it refers to 'a paired set of morphological concords' (Schuh 1995: 125) where one member of the pair refers to singular and the other member is its plural equivalent. Throughout the paper, 'noun class' will refer to the latter concept. ${ }^{2}$

\footnotetext{
${ }^{2}$ Abbreviations

$\mathrm{AM}=$ Agreement marker

ATR $=$ Advance Tongue Root

$\mathrm{C}=$ Consonant

$\mathrm{CM}=$ Noun class marker

LOC $=$ Locative

MRK = Marker

NUM $=$ Numeral

3PL $=3$ Person Plural

$\mathrm{PFX}=$ Prefix
}

\author{
$\mathrm{CMPL}=$ Class marker plural \\ $\mathrm{CONJ}=$ Conjunction \\ $\mathrm{DEF}=$ Definiteness marker \\ DEM = Demonstrative \\ $\mathrm{L}=$ Low tone \\ NEG $=$ Negative \\ ORD $=$ Ordinal \\ PRSPROG $=$ Present progressive \\ PSTPROG $=$ Past progressive
}

FUT $=$ Future tense

LSM= Lexical Subject Marker

INDEF $=$ Indefiniteness marker

INT $=$ Interrogative

LINK $=$ Linker

NP $=$ Noun Phrase

PRON $=$ Pronoun

PST $=$ Past

QTF $=$ Quantifier 
One of the remarkable features of the Niger-Congo phylum, as pointed out by Williamson and Blench (2000), is its elaborate noun classification system that facilitates number marking through affixation (usually prefixation, and sometimes suffixation). This system usually triggers agreement between the governing noun and other elements in the sentence.

The Niger-Congo phylum presents interesting data with respect to noun classification, in that, whilst some (especially the proto-Bantu(-like)) languages show a fully functional system, others (especially the Kwa) languages show (to a large extent) a vestigial system. We shall first look at the Bantu languages, and then the G-T-M (GhanaTogo-Mountain) languages (Kwa, Niger-Congo), both of which show an active system, using Swahili and Seles as representatives of the two groups, respectively.

Bantu languages have been described as having the most grammaticalized classification system, typically with about 15-20 different noun class distinctions. Prefixes, sets of class specific agreement markers and, to some extent, particular semantic content of a given class distinguish Bantu noun classes (cf. Maho 1999). Swahili, for instance, has a conventionally numbered class system, with class prefixes predominantly taking the CVform. Because Bantu classes are additionally distinguished by distinct agreement morphology, the Swahili classes 1 and 3, as well as 9 and 10, have the same class prefix, but a different agreement morphology. The table below gives an overview of the classes, the kind of concord exhibited in each class, and the semantic content that characterizes each group.

Table 1: Swahili noun classes (Crisma et. al 2011: 254)

\begin{tabular}{|c|c|c|c|c|c|c|}
\hline Class & $\begin{array}{l}\text { Class } \\
\text { Prefix } \\
\end{array}$ & example & Concord & $\begin{array}{c}\text { Referential } \\
\text { Concord }\end{array}$ & $\begin{array}{c}\text { possessive } \\
\text { Concord }\end{array}$ & 'meaning' \\
\hline 1 & $\mathbf{M}$ & mtu 'person' & $\mathrm{a} / \mathrm{yu}$ & ye & wa & \multirow[t]{2}{*}{ People } \\
\hline 2 & wa & watu 'people' & wa & $\mathbf{0}$ & wa & \\
\hline 3 & $\mathbf{M}$ & mti 'tree' & $\mathbf{u}$ & $\mathbf{0}$ & wa & \multirow{2}{*}{ Trees, plants } \\
\hline 4 & $\mathrm{mi}$ & miti 'trees' & i & yo & ya & \\
\hline 5 & $\mathrm{ji} / \varnothing$ & jicho 'eye' & li & 10 & la & \multirow{2}{*}{$\begin{array}{l}\text { Round things, } \\
\text { liquids, masses, } \\
\text { augmentatives }\end{array}$} \\
\hline 6 & & & & & & \\
\hline
\end{tabular}

RED = Reduplicant $3 \mathrm{SG}=3$ Person singular

$\mathrm{G}-\mathrm{T}-\mathrm{M}(\mathrm{L})=$ Ghana Togo Mountain
$1 \mathrm{SG}=1$ Person singular $\mathrm{SM}=$ Subject marker DIM= Diminutive affix
2SG $=2$ Person singular $\mathrm{NCS}=$ Noun Class System $\mathrm{DP}=$ Determiner Phrase 


\begin{tabular}{|c|c|c|c|c|c|c|}
\hline 7 & $\mathbf{K i}$ & kiti 'chair' & ki & cho & cha & \multirow[t]{2}{*}{$\begin{array}{l}\text { Artefacts, tools, manner, } \\
\text { diminutives }\end{array}$} \\
\hline 8 & $\mathrm{Vi}$ & viti 'chairs' & vi & vyo & vya & \\
\hline 9 & $\mathrm{n} / \varnothing$ & ndege 'bird' & i & уо & ya & \multirow[t]{2}{*}{ Animals, loanwords } \\
\hline 10 & $\mathrm{n} / \varnothing$ & ndege 'birds' & $\mathrm{zi}$ & zo & $\mathrm{za}$ & \\
\hline 11 & $\mathrm{U}$ & ubao 'board' & $\mathrm{u}$ & 0 & wa & $\begin{array}{l}\text { Long things, } \\
\text { Abstracts }\end{array}$ \\
\hline 15 & $\mathbf{k u}$ & $\begin{array}{l}\text { kuimba 'to } \\
\text { sing' }\end{array}$ & ku & ko & kwa & Infinitives \\
\hline 16 & (pa) & \multirow[t]{3}{*}{ mahali 'place' } & pa & po & pa & \multirow{3}{*}{ Locatives } \\
\hline 17 & $(\mathrm{ku})$ & & ku & ko & kwa & \\
\hline 18 & $(\mathrm{mu})$ & & $\mathrm{mu}$ & mo & mwa & \\
\hline
\end{tabular}

From the table, we notice that agreement morphology in many classes differs from the noun class prefix, although, except for class 1, the different agreement markers of each class can be related (morpho-phonologically) to one underlying form. We also see that nouns denoting humans typically show "animate agreement", i.e. concord and (sometimes) referential and possessive concord of class $1 / 2$, irrespective of the class of their noun class prefix.

In Swahili, and Bantu in general, modifiers and arguments in DP inflect for the gender and number features of the head noun:
a. ki-kombe
change
cheupe
7 cup
$7 \mathrm{my}$
7 white

'my white cup'

b. vi-kombe vyangu vyeupe

8-cup 8.my 8.white

'my white cups [Carstens 2008: 160] 

a. m-toto huyu m-dogo
1-child 1this 1-small
'this small child'

\section{b. wa-toto hawa wa-dogo \\ 2-child 2.this 2-small \\ 'these small children' [Carstens 2008: 160]}

From the Swahili examples above, we observe that in Bantu noun classes and number participate in various gender-like agreement relations inside the DP. Inside the DP, a gender-like agreement is realized with adjectives and most determiners and quantifiers.

Finally, is the question of whether Bantu nouns classes are semantically-driven, to which Bantuists share divergent views. Some opine that noun classification is built around a semantic core, and that class assignment is semantically motivated (cf. Moxley 1998; Palmer \& Woodman 2000; Hendrikse 2011; Selvik 2001; and Sagna 2008). Nouns of classes 1 and 2 are the best examples that can be used to corroborate this view, as they include almost exclusively nouns referring to humans, although not all such nouns are found in classes 1 and 2 .

Opposed to this, is the view held by Carstens 2008 inter alia, that assumes that noun class assignment is an arbitrary lexical quality, implying that it has to be learned during language acquisition and does not reflect any underlying semantic categorization. This view finds grounds in the fact that there are many 'exceptions' to semantic generalizations, even the most robust ones.

In the subsequent section, we shall deal with the NCS phenomena as it works across the Kwa sub-family (to which Esahie belongs) of the Niger-Congo phylum, so as to show its semblance with the Bantu system, as well as to put the Esahie noun classification system in its rightful typological perspective.

\subsection{Noun Classification in Kwa}

Aboh (2010), in an introductory remark on the morpho-syntax of the Kwa DP, contends that most (Kwa) languages have completely lost their noun class system and, as a consequence, make no distinction between singular/plural forms. Interestingly however, 
while some languages (including Akan) show an almost-lost system, others (particularly the GTM languages such as Seles) in contrast show a fully developed one.

In this section, I give a closer look at the noun classification system (NCS) of the Kwa languages, by first drawing a distinction between those that show a functional system, such as $\mathrm{S} \varepsilon l \varepsilon \varepsilon^{3}$, as earlier hinted, and those that exhibit a somewhat inactive system, such as Esahie.

\subsubsection{Noun Classification in G-T-M}

Contrary to what has been argued that a majority of Kwa sub-family languages tendentially lack an active NCS, the G-T-M languages, as we shall see, have a system similar to what we earlier saw in Bantu with data from Swahili. For Seleq (G-T-M), Agbetsoamedo (2014: 80) proposes eight classes. The table below gives a general overview of the various classes and their respective agreement markers that are used to indicate concord both within and outside the DP.

Table 2: Noun class markers and agreement targets in Seles (adapted from Agbetsoamedo 2014: 80)

\begin{tabular}{|l|l|l|l|l|l|l|l|l|}
\hline $\begin{array}{l}\text { Noun } \\
\text { Class }\end{array}$ & Prefix & \multicolumn{1}{|c|}{ Example } & AAM & Obj. Pro & Def. & Dem & Num & $\begin{array}{l}\text { Int. } \\
\text { Pro }\end{array}$ \\
\hline 1 & o-/ J-/ $\varnothing$ & o-tii 'person' & ku-/a- & nwu/nws & wo & wo- & o- & ว- \\
\hline 2 & ba- & ba-pe 'plant' & ba- & ma & ba & ba- & ba- & ba- \\
\hline 3 & ka- & ka-futu 'stomach' & ka- & kã & ka & ka- & ka- & ka- \\
\hline
\end{tabular}

\footnotetext{
${ }^{3}$ Later in the discussion, we shall look at Tutrugbu, another G-T-M language, comparing its NCS to Esahie.
} 


\begin{tabular}{|c|c|c|c|c|c|c|c|c|}
\hline 4 & $\begin{array}{l}\text { si-/se- } \\
/ \text { se - }\end{array}$ & $\begin{array}{l}\text { se-lec 'Santrokofi } \\
\text { language' }\end{array}$ & si- & sĩ & se & se- & e- & $s \varepsilon-$ \\
\hline 5 & $\begin{array}{l}\text { di-/li- } \\
/ \text { ni-/le- } \\
/ 1 \varepsilon-\end{array}$ & di-si 'head' & di- & ni & le & le- & ni- & $1 \varepsilon-$ \\
\hline 6 & $\mathrm{n}-$ & n-nonyi 'oil' & $\mathrm{n}-$ & $\mathrm{mi}$ & be & be- & $\mathrm{n}-$ & $\mathrm{m}-$ \\
\hline 7 & $\begin{array}{l}\text { ku-ko- } \\
\text { /kJ- }\end{array}$ & kokpaku 'fishes' & $\begin{array}{l}\text { ku-ko- } \\
\text { /kJ- }\end{array}$ & kũ & ko & ko- & ku- & $\begin{array}{l}\text { ku- } \\
\text { ko- } \\
\text { /ko- }\end{array}$ \\
\hline 8 & a- & a-fecfo 'air' & a- & nya & ya & ya- & a- & a- \\
\hline
\end{tabular}

Agbetsoamedo notes, among other things, that Seles nouns trigger agreement on their syntactically dependent elements within and outside the DP. More specifically, she points out that in Seles, determiners, numerals and interrogative pronouns agree with their controller nouns, adding that adjectives, on the contrary, do not generally show agreement, but occasionally one of two or three adjectives in an NP may take an agreement marker. While in examples (3) and (4), we observe agreement between the head the noun and its modifying determiners, in example (5), we observe agreement between the head noun and its modifying numerals.
(3)

$\begin{array}{ll}\text { ko-leele } & \text { ko-mle } \\ \text { 7-harmattan } & \text { 7-this }\end{array}$
o-bè
kanto
ma-fuo
1-time
rain
LSM.FUT-can 
o-nos

3SG-fall

'This harmattan season ${ }^{4}$, the rain can (really) fall.'

(4)

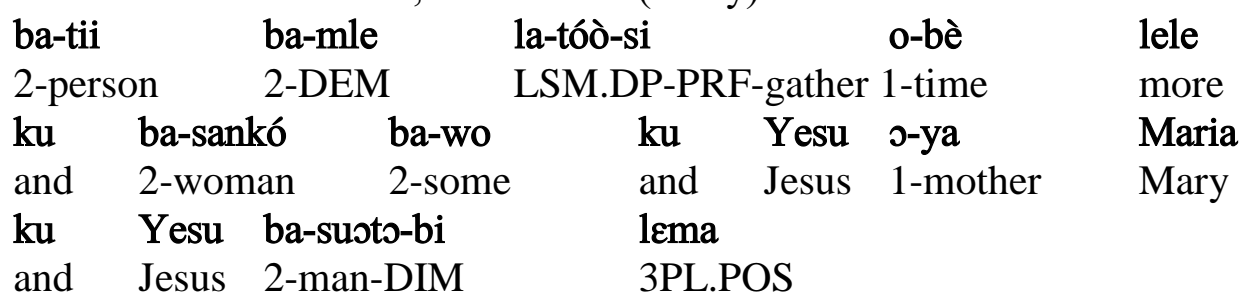

'These people were gathering every time with some women and Jesus' mother Mary and Jesus' brothers [...].'
a. ka-fusuka-nwii
3-rat 3-one
b. n-fusu
n-nyo
6-rat 6-two
'two rats'

Like Bantu noun classes, the class system in Seleq also shows a certain amount of semantic consistency. In the table below, Agbetsomedo (2014: 106) provides a semantic underpinning for Seleq noun classification.

\footnotetext{
${ }^{4}$ Harmattan is a very dry and humid weather season that usually begins in January.
} 
Table 3: The semantics of classes (adapted from Agbetsoamedo 2014: 106)

\begin{tabular}{|c|c|c|c|}
\hline Class & Frequency & Prefixes & Semantics \\
\hline \multirow[t]{2}{*}{$1 / 2$} & \multirow[t]{2}{*}{$26.6 \%$} & o-/ ग-; ba- & Human terms (identity, kinship). \\
\hline & & $\varnothing-;$ ba- & $\begin{array}{l}\text { Mostly derived human referents, } \\
\text { some animals, } \\
\text { nouns. }\end{array}$ \\
\hline $5 / 8$ & $28.7 \%$ & $\begin{array}{l}\text { di-/li-/ni-/le- } \\
/ 1 \varepsilon-; \text { a- }\end{array}$ & $\begin{array}{l}\text { Animal offspring; body parts, } \\
\text { Food and Other things with } \\
\text { round/circular, oval or concave } \\
\text { shape. }\end{array}$ \\
\hline $7 / 8$ & $10.1 \%$ & $\begin{array}{l}\text { ko-/ko-/ku-; } \\
\text { a- }\end{array}$ & $\begin{array}{l}\text { Long things with flat surfaces, } \\
\text { farm and farm-related concepts }\end{array}$ \\
\hline $1 / 4$ & $15.7 \%$ & $\begin{array}{l}\text { o-/つ-; se-/se- } \\
\text { /si- }\end{array}$ & 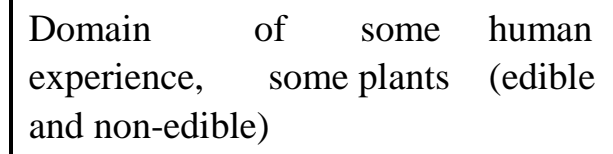 \\
\hline $3 / 6$ & $16.4 \%$ & ka-; n- & $\begin{array}{l}\text { Most external body parts, mass } \\
\text { nouns, location/places }\end{array}$ \\
\hline $3 / 7$ & $1.1 \%$ & $\begin{array}{l}\text { ka-; ko-/ko- } \\
\text { /ku- }\end{array}$ & $\begin{array}{l}\text { Diminutives; 'fish' } \\
\text { and 'ant' }\end{array}$ \\
\hline $7 / 6$ & $0.7 \%$ & $\begin{array}{l}\text { ko-/kJ-/ku-; } \\
\text { n- }\end{array}$ & Limbs: hand and leg \\
\hline $1 / 8$ & $0.7 \%$ & o-/J-; a- & Running stone and corn \\
\hline
\end{tabular}


Notwithstanding the seeming semantic features and cultural undertones that correlate with the classes, as shown in the table, Agbetsoamedo (2014) finally takes the position that the motivation for the assignment of a majority of nouns to their respective classes is generally arbitrary.

As has been suggested for Swahili by Schadeberg (2001), the singular-plural pairing of classes of Bantu, (and by extension G-T-M languages), could be explained as a lexical derivational relationship involving semantic notions of individuals and groups, while in terms of grammatical category, class/gender, rather than number, is the relevant feature.

Below are some preliminary generalizations on some shared similarities between the Bantu (i.e. Swahili) and G-T-M (i.e. Selec, Kwa) class systems.

a. Both Bantu and GTM (Kwa) have a gender-like NCS.

b. Both Bantu and GTM have a comparatively high number of distinctive classes/genders.

c. Both Bantu and GTM express number in gender-particular prefixes.

d. The agreement system in both languages is fairly active.

e. Phonologically, most class/agreement markers take the $\mathrm{CV}$-form.

Having shown the semblance between the Bantu and GTM (Kwa) languages, with both showing a functional system, we shall now take a look at another sub-group of Kwa languages that show a residual or inactive system, namely the Central-Tano sub-group, using Akan as a starting point. The choice of Akan finds justification on grounds that, apart from the fact of Akan showing a vestigial class system (making it similar to Esahie, as we shall see), genetically, Akan is also closely related to Esahie, at least because they both belong to the Central-Tano sub-family.

\subsubsection{NCS in Akan}

In this section, we take a cursory look at what has been described regarding noun classification in the Akan literature, to take some cues. In general, there are two positions on the status of NCS in Akan, and we shall discuss them in what follows.

In the first, it is argued by Osam (1993), Aboh (2007), and Ameka (2008), and shared by Appah (p.c.), that, in synchronic Akan, the NCS as syntactically active system is lost. In an attempt to account for why other Akanists may misguidedly conclude that Akan has an active noun class system, Osam first identifies among other possible grounds, 
one, Akan's genetic affiliation to (what is now known as) the G-T-M languages which show an active system, two, morphological evidence in the form of prefixes borne by both singular and plural nouns, and finally, morpho-syntactic evidence in the form of number agreement. To corroborate his stance, however, Osam appeals to evidences of morphological decay that is observed in the loss of singular noun prefixes, frozen plural nouns, and the complete loss of nominal prefixes. In the examples below, for instance, we observe that the nouns in their singular are zero-marked, as evident in (6).

\begin{tabular}{|c|c|c|}
\hline$\underline{\text { Stem }}$ & $\underline{\text { Singular }}$ & Plural \\
\hline ant & tetea & n- tetea \\
\hline pig & prako & m-prako \\
\hline name & dzin & e-dzin \\
\hline
\end{tabular}

(Osam 1993)

He however, adds that nouns that show this behaviour tend to be either non-human animate or inanimate nouns, and that human nouns hardly lose their prefixes, implying some sort of restriction.

Osam also resorts to evidences of morpho-syntactic decay seen in frozen forms of adjectival prefixes and loss of number prefixes borne by adjectives. Regarding frozen plural adjectives, he shows that there is no noun-adjective class agreement in synchronic Akan. He explains more specifically that, when both noun and adjective are marked for plural, the form of the marker borne by the adjective is not dependent on the form of the marker borne by noun. This lack of agreement is shown below in (7).
a.
a-tar tuntum
SG-dress black
'black dress'
Singular
b. kyen kakraba
drum small
'small drum'

\section{$\underline{\text { Plural }}$}
n-tar e-tuntum
PL-dress PL-black
'black dresses'
a-kyen n-kakraba
PL-drum PL-small
'small drums' (Osam 1993)

From example (7) we notice that a plural noun can be modified by an adjective that has a different plural prefix. In (7a), for example, the plural noun has a nasal prefix, but the adjective's prefix is a vocalic one. Similarly, the noun in (7b) has a vocalic prefix but its 
modifying adjective has a nasal prefix. Still on the issue of morpho-syntactic decay, Osam turns to the loss of number prefixes (expected to be) borne by adjectives as additional evidence. He shows that apart from the inconsistent concordial relation between the noun and adjective plural prefixes, as witnessed from example (7) above, not all Akan adjectives take the plural marker. This is exemplified below in (8)

Singular

atar hahar 'light dress'

dua dudur 'heavy log'
Plural

n-tar (*a-)hahar 'light dresses'

n-dua (*c-)dudur 'heavy logs'

(Osam 1993)

As further evidence of the extent of decay in the Akan class system, Osam considers singular adjectives. He observes that all adjectives have lost their prefixes in the singular and as a result, there is no agreement between a singular noun and the adjective that modifies it as shown in (9).

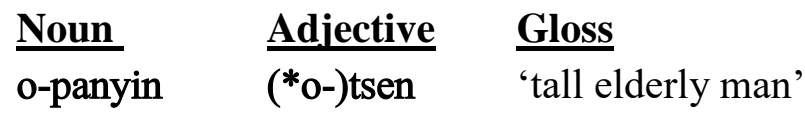

$$
\begin{aligned}
& \text { J-dan (*:J-)kese 'big building' } \\
& \text { o-dwan }\left(*^{\circ}\right. \text {-)ketewa 'small sheep' }
\end{aligned}
$$

(Osam 1993)

Finally, Osam appeals to the pervasive loss of verbal concord in Akan as further grounds for his position. He argues that, unlike Bantu where the choice of a noun controls the choice of the agreement marker on the verb, the case of Akan is different. Osam explains that, the fact that most dialects of Akan have lost the agreement system leaves Akan with hardly any verbal concord. Despite admitting that the Fante and Bron dialects show traces of a frozen verb agreement, Osam demonstrates that even in Fante, the choice of a noun does not control the choice of the (number) agreement marker on the verb as demonstrated in (10).
a. a-bowa
no
o-bo-wu
b. *a-bowa
no
a-bo-wu
SG-animal the 3SG-FUT-die
'The animal will die'
SG-animal the 3SG-FUT-die
(Osam 1993) 
One would have expected that since the subject of (10) bears the $a$-prefix, the same $a$-prefix would be selected for the verb to show agreement. However, in (10a), the agreement on the verb is the $o$-prefix. Changing this to the expected $a$-prefix renders (10b) ungrammatical. Premised on these basis, Osam concludes that though Akan might have once had a syntactically active noun class system, synchronically speaking, the system is lost.

In the other view, Bodomo and Marfo (2006) opine that Akan still has a class system. They argue that distinctive noun classes based on number affixation can be established for Akan. Accordingly, they group nouns into classes based on the similarity of both the singular and plural affixes. They explicate that the Akan noun class systems based mainly on an interface between the morphological and phonological components of the grammar. More specifically, they show that (ATR) vowel harmony and assimilation are very crucial phonological phenomena that dictate the choice of a particular number affix.

However, they seem to have concentrated only on the morpho-phonologically relevant aspects, ignoring other aspects one would have considered as being very critical, namely, the morpho-syntax of the Akan NCS. As a result, they are completely silent on whether the Akan NCS is a morpho-syntactically active one. For instance, they fail to look at agreement phenomena within and outside the Akan DP. As Creissels (2013) rightly points out, regarding noun classification in the general Niger-Congo family, it is impossible to isolate morphological elements whose sole function is to express number. It appears that the main reason why Bodomo and Marfo (ibid) argue for an active system is because of the syntactic feature of number, which could be considered as merely an abstract feature. Assuming without admitting, that number was not just a superficial feature as far as noun classification itself is concerned, they still fail to show whether or not number triggers agreement with other elements within and outside the DP. Moreover, the singular-plural pairings put forward in Bodomo and Marfo appear to be arbitrary and unpredictable, a point they accept. Still on number marking, as Osam (1993) rightly points out, Akan has suffered a substantial deal of morphological decay resulting in the partial loss of (singular) noun prefixes, complete loss of nominal prefixes, and the incidence of frozen plural nouns. Looking beyond the deficiency observed with respect to number marking, Osam further observes that synchronic Akan hardly has any verbal concord.

A critical look rather shows that the agreement system of Akan is one that could be fittingly described as weak(-ened) and highly restricted. That notwithstanding, as we shall 
see (section 6.0), it would be inaccurate to classify Akan as an entirely gender-less (i.e. no agreement) language.

The two positions arrived at regarding the status of the Akan NCS cannot be seen as contrasting as a result of the fact that, different methodological and analytical approaches are adopted in both, one being purely morpho-syntactic in scope, and the other being purely morpho-phonological. While Osam (1993) focuses on showing that NCS in synchronic Akan is a morpho-syntactically decayed one, Bodomo and Marfo (2006), on the other hand, focus on how morpho-phonological information feed into selection of one number affix over the other. The point of agreement maintained by both, however, is that, the Akan NCS is a number-based one. Overall, the two positions arrived regarding the status of the Akan NCS could be conveniently described as "two sides of the same coin".

Having seen what obtains in Akan, a closely related sister, we shall now return to Esahie to, first, discuss some general phonological issues (which actually apply generally across Kwa) that are crucial to our understanding of the Esahie NCS (section 3.0), then proceed to look at the Esahie NCS itself (section 4.0). We will first consider some general grammatical properties of Esahie, so as to understand some of the analyses rendered in this work. We shall first take a look at Esahie and its language family, and proceed to give a brief grammatical introduction of the syntax, phonology and finally its morphology.

\section{General Overview of Esahie}

Esahie has been alternatively referred to as Asahyue, Sanvi and Sehwi, and coded in Ethnologue as [ISO 639-3: sfw]. Esahie belongs to the Northern Bia family of the Central-Tano subgroup (Dakubu and Dolphyne, 1988). Esahie is genetically close to Aowin and Nzema and falls in the same language family with Anyi as shown in the Kwa language family tree in Figure 1 below. 


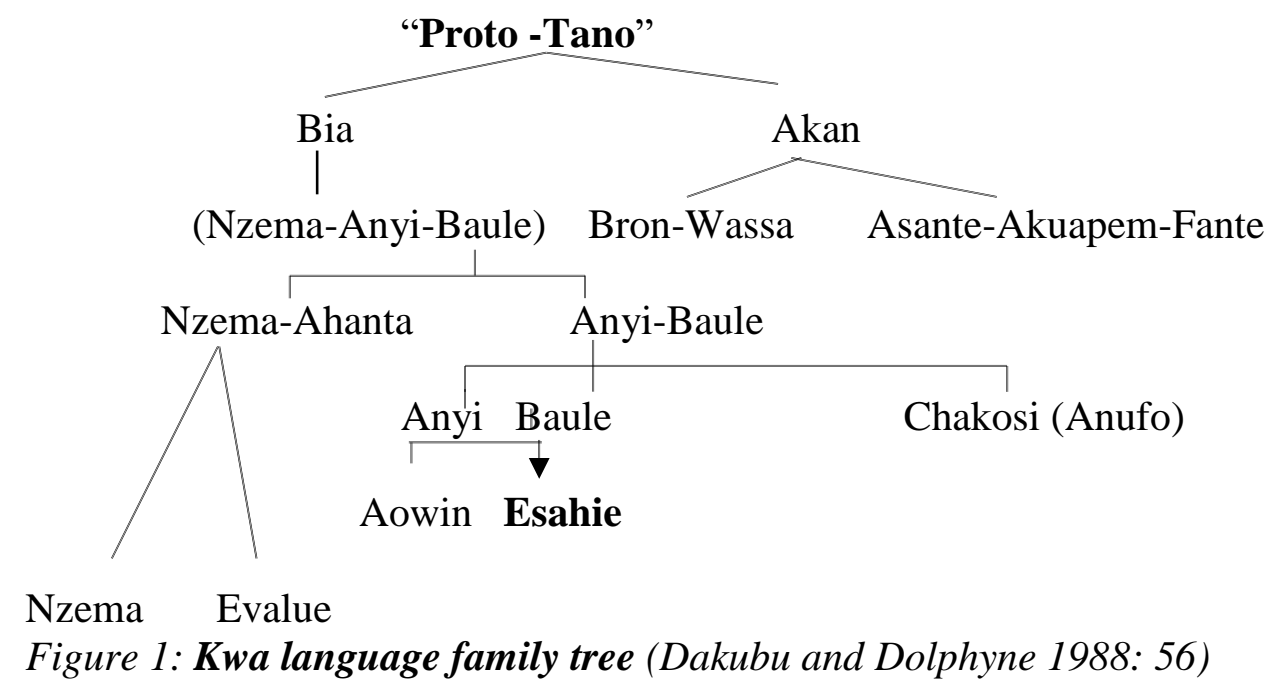

Figure 1 shows that under the Bia language group, the first split was between Nzema and Ahanta, on one side, and Anyi and Baule, on the other side. Thereafter, Anyi, Baule, and Chakosi split from each other. Anyi then also split into Anyi (Aowin) and Sehwi (Esahie).

Ntumy and Boafo (2002) identify two varieties of Esahie. The first one is the Anhwiaso variety, which is spoken in the extreme east of the area, that is, east of the River Subraw in towns like Sehwi-Anhwiaso, Sehwi-Bekwai, and Asawinso. The second one is the Wiawso variety, which is the major variety in use, in the wider area, westwards of the River Subraw. ${ }^{5}$

Syntactically, Esahie, like Akan, and indeed many other Kwa languages (cf. Aboh and Essegbey 2010), is a strictly SVO language. Being a nominative-accusative language, the (A) argument ${ }^{6}$ precedes the verb and the (P) argument ${ }^{7}$ follows the verb in a simple transitive clause. The $\mathrm{S}$ argument of an intransitive clause also precedes the verb, as exemplified in (11).

a. Salo po-le ataade $\quad$ ne
Salo wash-PAST dress
'Salo washed the dress'

${ }^{5}$ The data for this work will be drawn mainly from the latter variety.

${ }^{6}$ Agent

${ }^{7}$ Patient. 


\section{b. Salo la-le \\ Salo sleep-PAST \\ 'Salo slept'}

Morphologically, it would be most suitable to categorize Esahie as typologically isolating, in consonance with what has been observed generally for Kwa (cf. Aboh and Essegbey 2010). As such, one characteristic feature of Esahie is that it has a fairly limited inflectional morphology. Consequently, lexical DPs are not inflected for case, but only for number, as is seen in example (12).
a. tcía a-hye
e-bote
dog PERF-catch SG.rabbit
b. ebote
a-hye
t6ía
'A dog has caught a rabbit'
rabbit PERF-catch dog
'A rabbit has caught a dog'

\subsection{Phonological features of the Esahie Language}

As Frimpong (2009) points out, Esahie is one of the many tonal languages of Ghana. On the tonology of Esahie, she observes two basic contrastive tones in Esahie: a high tone, denoting a relatively high pitch, and a low tone, denoting relatively low pitch. In what follow, I will briefly discuss some other phonological phenomena that apply at the morpheme/word boundaries, including vowel harmony and assimilation.

\subsubsection{Vowel Harmony (VH)}

The most relevant phonological information is the advanced tongue root (ATR) vowel harmony principle. Esahie has ten vowel phonemes. The two sets of vowels are distinguished by the feature [ATR]. In virtue of the vowel harmony principle, the ten vowels of Esahie fall into two phonetically distinctive classes, i.e. a vowel is either produced with an advanced tongue root or an un-advanced tongue root.

a. Set I: [+ATR]: [i, u, e, æe, o]

b. Set II: [-ATR]: [I, $\boldsymbol{\sigma}, \boldsymbol{\varepsilon}, \mathbf{a}, \boldsymbol{\jmath}$ ] (cf. Frimpong 2009) 
Following the distinction, all stem vowels are required (or at least expected) to be of a common ATR feature specification. Unless a stem is underlyingly disharmonic, ATR harmony in Esahie is stem-controlled. Affixes are usually underspecified for ATR, such that, if the vowel(s) of the stem is [+ATR], one of the following vowels of the affix /i, $\mathbf{u}$, $\mathbf{e}, \mathfrak{a}, \mathbf{o} /$ will be selected. If, on the other hand, it is [-ATR], the vowels selected will be one of these: /I, $\boldsymbol{\sigma}, \boldsymbol{\varepsilon}, \mathbf{a}, \mathbf{\jmath} /$. Take for instance, the words $\boldsymbol{\varepsilon}$ tina 'cloth' and ebote 'grass cutter'. Phonologically, we can observe (ATR) VH at work in the selection of the singular prefix for both words. The rule below explains the differences between the prefix in $\varepsilon$-tina and ebote:

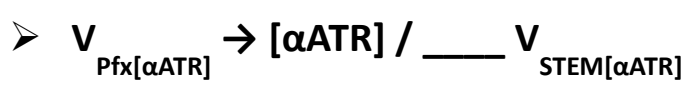

\subsubsection{Assimilation}

Another pervasive phenomenon in Esahie morpho-phonology is assimilation, most commonly, homorganic nasal assimilation (henceforth HNA) and consonant mutation. Esahie consonant mutation may occur as a case of voicing assimilation (henceforth VA) or glottalization. As an exemplification of these phenomena, let's discuss the case of plural formation. The most productive plural marker is the morpheme /N/ which has an unspecified place of articulation when it precedes a consonant. It has a zero place of articulation and agrees in place with the consonant following it. The nasal can become a bilabial (as in (13)), a labio-dental, an alveolar, a palatal (as in (14)) or a velar (as in (15)) before a bilabial, a labio-dental, an alveolar, a palatal or a velar, respectively. This is exemplified below:

$$
\begin{aligned}
& \begin{array}{lll}
\text { pure } & \rightarrow \mathbf{N}+\text { pure } \\
\text { squirrel.SG } & \text { PL+ squirrel }
\end{array} \rightarrow \begin{array}{l}
\text { mbure } \\
\text { 'squirrels' }
\end{array} \\
& \text { tcia } \rightarrow \mathrm{N}+\text { tcia } \rightarrow \text { nd;ia } \\
& \text { dog.SG } \mathrm{PL}+\operatorname{dog} \text { 'dogs' }
\end{aligned}
$$

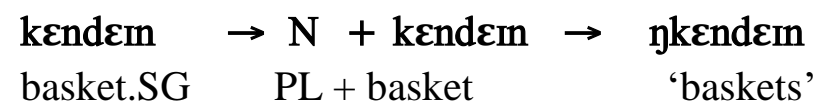


Apart from HNA, we also observe VA from the data above. In example (13), the nasal spreads its voicing onto the voiceless bilabial stop /b/, causing it to assimilate into a voiced sound. Similarly, in example (14) a voiceless velar stop becomes voiced as a result of the presence of a nasal. Unlike what obtains in HNA and $\mathrm{VH}$, VA shows a regressive directionality since it is the affix that is the trigger.

The rules below account for both phenomena which are triggered by the plural formation, respectively.

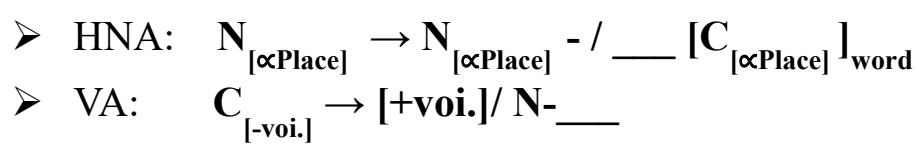

\subsubsection{Lenition}

Lenition in Esahie is morpho-phonologically conditioned, and usually involves a voiceless velar stop mutating into a glottal fricative when it occurs intervocalically. With regards to nouns, it typically occurs (at morpheme boundary) when the plural prefix /a-/ is attached to nouns beginning in a voiceless velar stop.

$$
\begin{array}{ll}
\text { ko } \rightarrow & \text { /a/ }+ \text { ko/ } \\
\text { war.SG } & \text { PL+ war aho }
\end{array}
$$

This rule below explains the data above:

- Rule: / k/ $\rightarrow / \mathrm{h} /[+$ voi $] /[$ [+voi $]$

Lenition is, however, not general in Esahie. There are cases where $/ \mathrm{k} /$ is not glottalized intervocalically. For pluralization, nouns that appear to be borrowed from Akan tend to block this rule. This accounts for why kuanie 'farmer' which selects the plural marker /a-/ has its plural form as akuafuc 'farmers', and not ahuafue.

In spite of all of these general features established so far, Esahie still remains a highly understudied Kwa language, on which virtually no morphological investigation has been performed so far, hence the need for the present study.

\section{Noun Form/Declension Classes in Esahie}


Drawing inspiration from on what has been argued for Akan, a sister (Central-Tano) language, in Osam (1993) and Bodomo and Marfo (2006), six (6) distinctive noun form classes (declension classes) can be established in Esahie. In setting up various noun form groupings for Esahie, this work primarily puts nouns into classes based on the morphological similarity of both the singular and plural affixes. This criterion of classification implies that nouns belong to one and only one class, whether in the singular or plural. The singular-plural pairing in the classes can be explained as a grammaticalinflectional relationship involving the grammatical category of number. The defining criterion for the grouping is based (predominantly) on similarity in plural affixes borne by the noun.

The motivation for this criterion lies in the fact that though the nouns may vary in terms of the kind of singular marker(s) they select, for the plural most of these nouns eventually select a common marker(s), suggestive of the fact these nouns form a natural class. Another motivation for this criterion is that it reduces the overall number of classes to a smaller set. As we shall see, the largest class of Esahie nouns are zero-marked in their singular, implying grouping them according to the singular affixes might be a bit problematic.

Table 4: Noun Form/Declension Class Table

\begin{tabular}{|c|c|c|c|c|}
\hline & Stem & Singular Form & Plural Form & Productivity \\
\hline Class 1 & & $(\mathrm{~V}-)$ & $\mathrm{N}-$ & Very High \\
\hline a. A-/N- & $\begin{array}{l}\text {-bongye } \\
\text {-ko } \\
\text {-tadec } \\
\text {-nomaa } \\
\text {-tekra } \\
\text {-kwaadu }\end{array}$ & $\begin{array}{l}\text { abongye } \\
\text { 'goat' } \\
\text { ako } \\
\text { 'fowl' } \\
\text { atadec } \\
\text { 'dress' } \\
\text { anomaa } \\
\text { 'bird' } \\
\text { atckra } \\
\text { 'feather' } \\
\text { akwaadu } \\
\text { 'banana' }\end{array}$ & 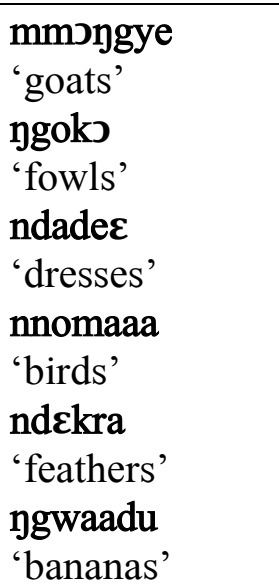 & \\
\hline
\end{tabular}




\begin{tabular}{|c|c|c|c|}
\hline & $\begin{array}{l}\text {-koa } \\
\text {-kolaa } \\
\text {-brande } \\
\text {-pena } \\
\text {-fiale }\end{array}$ & $\begin{array}{l}\text { akoa } \\
\text { 'slave/servant' } \\
\text { akolaa } \\
\text { 'child' } \\
\text { abrandec } \\
\text { 'young man' } \\
\text { apena } \\
\text { 'bat' } \\
\text { afiale } \\
\text { 'hide out' }\end{array}$ & 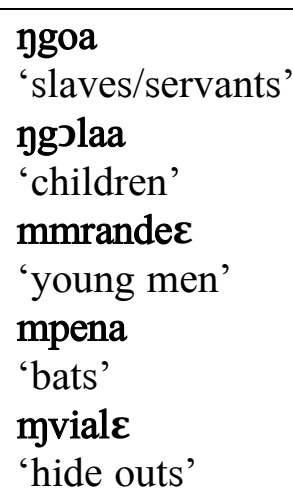 \\
\hline b. $\quad$ E-/N- & $\begin{array}{l}\text {-kra } \\
\text {-woo } \\
\text {-tena } \\
\text {-bote } \\
\text {-nwomee }\end{array}$ & $\begin{array}{l}\text { عkra } \\
\text { 'cat' } \\
\text { ewoo } \\
\text { 'snake' } \\
\text { Etina } \\
\text { 'cloth' } \\
\text { ebote } \\
\text { 'rabbit' } \\
\text { Enwomee } \\
\text { 'ghost' }\end{array}$ & $\begin{array}{l}\text { ygra } \\
\text { 'cats' } \\
\text { nwoo } \\
\text { 'snakes' } \\
\text { ndina } \\
\text { 'cloths' } \\
\text { mmote } \\
\text { 'rabbits' } \\
\text { nnwomee } \\
\text { 'ghosts' }\end{array}$ \\
\hline $\begin{array}{l}\text { c. } \\
\varnothing / \mathbf{N}-\end{array}$ & $\begin{array}{l}\text {-pure } \\
\text {-kendein } \\
\text { - tcía } \\
\text {-brasua } \\
\text {-brenzua }\end{array}$ & $\begin{array}{l}\text { pure } \\
\text { 'squirrel' } \\
\text { kendem } \\
\text { 'basket' } \\
\text { tcía } \\
\text { 'dog' } \\
\text { brasua } \\
\text { 'female/lady' } \\
\text { brenzua } \\
\text { 'male/guy' }\end{array}$ & $\begin{array}{l}\text { mbure } \\
\text { 'squirrels' } \\
\text { ygendemn } \\
\text { 'baskets' } \\
\text { j̀dzià } \\
\text { 'dogs' } \\
\text { mmrasua } \\
\text { 'females/ladies' } \\
\text { mmienzua } \\
\text { 'males/guys' }\end{array}$ \\
\hline
\end{tabular}




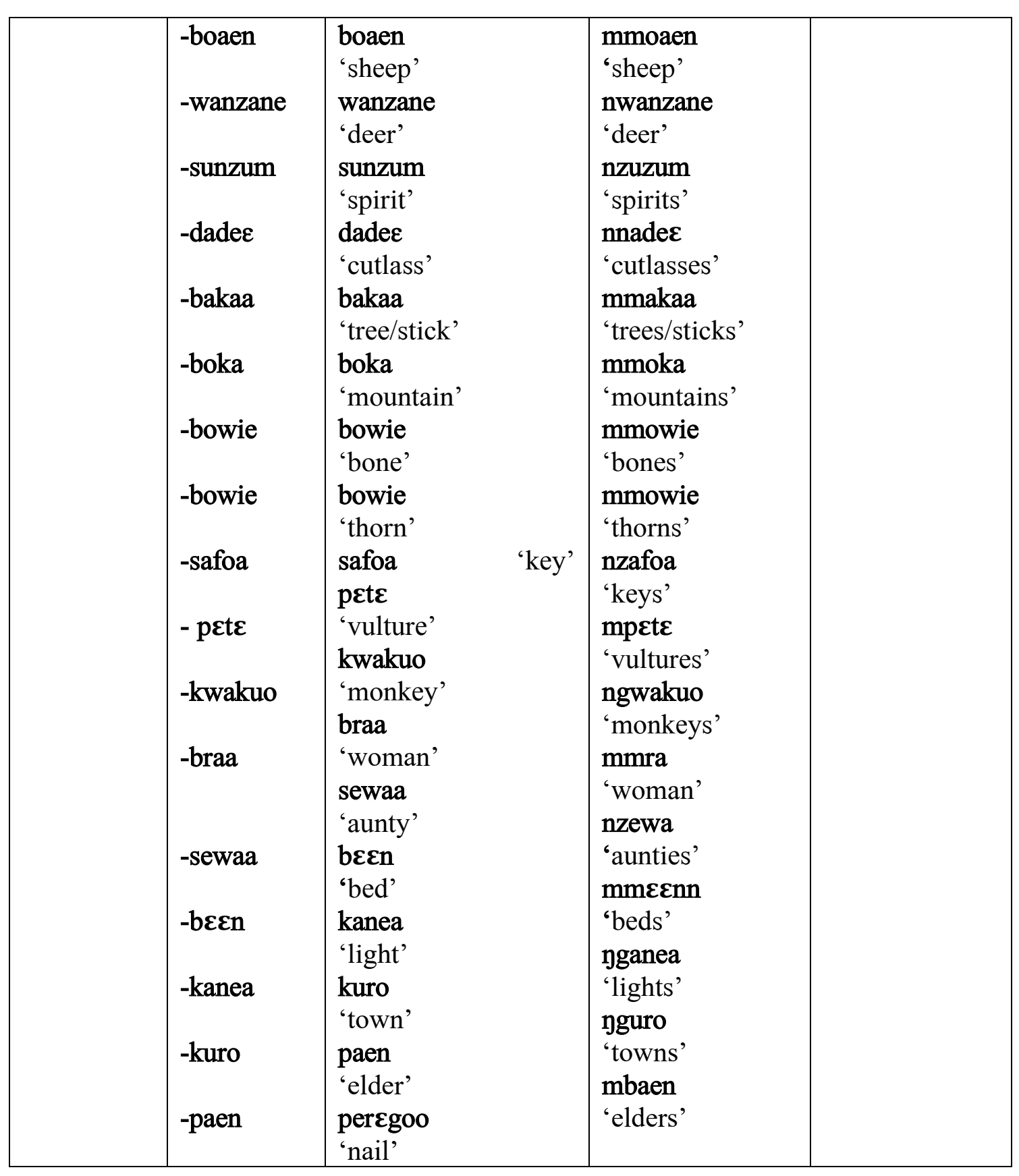




\begin{tabular}{|c|c|c|c|c|}
\hline & $\begin{array}{l}\text {-perعgoo } \\
\text {-taluwa } \\
\text {-soa } \\
\text {-soe } \\
\text { tcrrenmvua } \\
\text { - }\end{array}$ & $\begin{array}{l}\text { taluwa } \\
\text { 'lady' } \\
\text { soa } \\
\text { 'insult' } \\
\text { soe } \\
\text { 'ash' } \\
\text { tcirenmvua } \\
\text { 'egg' }\end{array}$ & $\begin{array}{l}\text { mbercgoo } \\
\text { 'nails' } \\
\text { ndaluwa } \\
\text { 'ladies' } \\
\text { nzoa } \\
\text { 'insults' } \\
\text { nsoe } \\
\text { 'ashes' } \\
\text { ndpIrenmvua } \\
\text { 'eggs' }\end{array}$ & \\
\hline Class 2 & & \multicolumn{2}{|l|}{$(\mathrm{V}-)$} & \\
\hline a. $V$-/A- & $\begin{array}{l}-1 \varepsilon n \\
-m a m a\end{array}$ & $\begin{array}{l}\text { elen } \\
\text { 'canoe' } \\
\text { गmama } \\
\text { 'prominent person' }\end{array}$ & $\begin{array}{l}\text { alsn } \\
\text { 'canoes' } \\
\text { amama } \\
\text { 'prominent } \\
\text { person' }\end{array}$ & Low \\
\hline b. $\emptyset-/ A-$ & $\begin{array}{l}-k o \varepsilon \\
-s \supset f o\end{array}$ & $\begin{array}{l}\text { koe } \\
\text { 'war' } \\
\text { sofo } \\
\text { 'pastor' }\end{array}$ & $\begin{array}{l}\text { ahoe } \\
\text { 'wars' } \\
\text { asofo } \\
\text { 'pastors' }\end{array}$ & \\
\hline & & $(V)-$ nie & A-_foe & \\
\hline $\begin{array}{l}\text { c. } \boldsymbol{A}-/ \boldsymbol{A}- \\
\text { Identi- } \\
\text { ficational/ } \\
\text { Occupation } \\
\text { al }\end{array}$ & $\begin{array}{l}\text {-wie } \\
\text {-sande } \\
\text {-safo } \\
\text {-ware } \\
\text {-agudi } \\
\text {-mano }\end{array}$ & 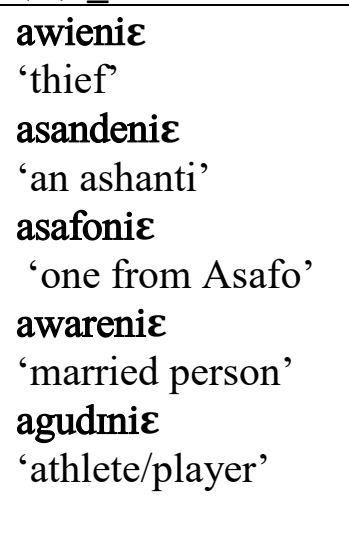 & 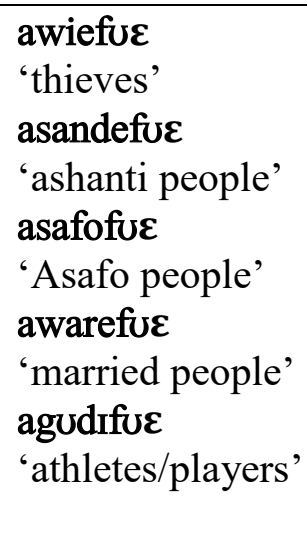 & \\
\hline
\end{tabular}




\begin{tabular}{|c|c|c|c|c|}
\hline & $\begin{array}{l}\text {-sosi } \\
\text {-nisi } \\
\text {-fiase }\end{array}$ & 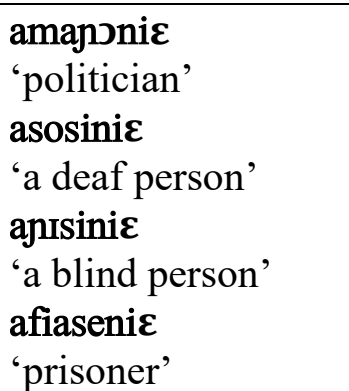 & 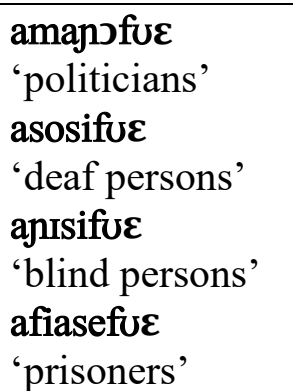 & \\
\hline $\begin{array}{l}\text { d. } \boldsymbol{\emptyset}-/ \boldsymbol{A}- \\
\text { Identificati } \\
\text { onal/ } \\
\text { Occupation } \\
\text { al }\end{array}$ & 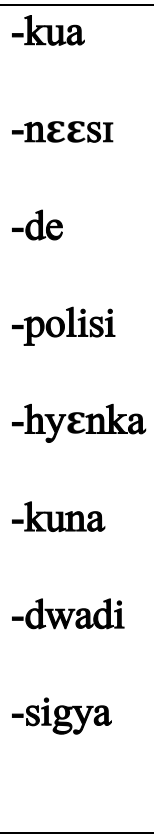 & 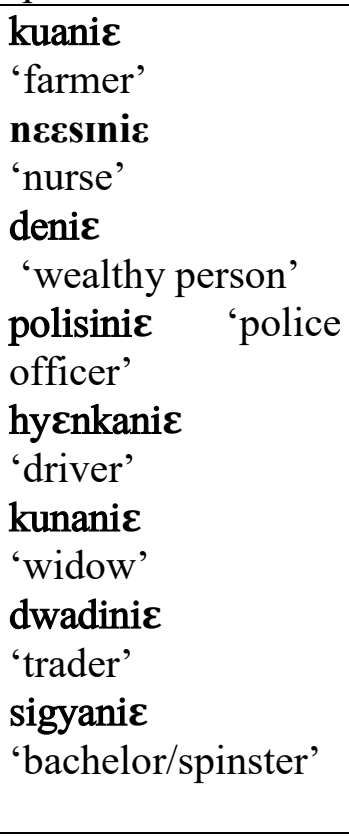 & 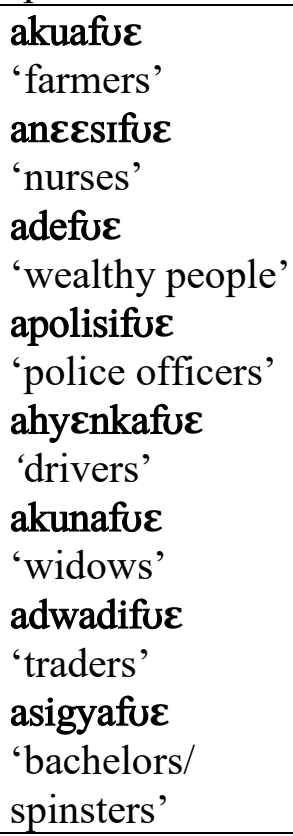 & \\
\hline \multicolumn{5}{|l|}{ Class 3} \\
\hline +kinship & & V-/Ø- & / Ø-_-mכ & Low \\
\hline a. V-/A-m了 & -liemaa & $\begin{array}{l}\text { aliemaa } \\
\text { 'sibling' }\end{array}$ & $\begin{array}{l}\text { aliemaams } \\
\text { 'siblings' }\end{array}$ & \\
\hline $\begin{array}{l}\text { b. } \emptyset-/ \emptyset_{-}= \\
m s\end{array}$ & $\begin{array}{l}\text {-sewaa } \\
\text {-wofa }\end{array}$ & $\begin{array}{l}\text { sewaa } \\
\text { 'aunty' } \\
\text { wofa } \\
\text { 'uncle' }\end{array}$ & $\begin{array}{l}\text { sewaams } \\
\text { 'aunties' } \\
\text { wofams } \\
\text { 'uncles' }\end{array}$ & \\
\hline
\end{tabular}




\begin{tabular}{|c|c|c|c|c|}
\hline & $\begin{array}{l}\text {-nana } \\
\text {-baba } \\
\text {-ye } \\
- \text { nic } \\
\text {-sia }\end{array}$ & $\begin{array}{l}\text { nana } \\
\text { 'grand..' } \\
\text { baba } \\
\text { 'father' } \\
\text { ye } \\
\text { 'wife' } \\
\text { nic } \\
\text { 'mother' } \\
\text { sia } \\
\text { 'inlaws' }\end{array}$ & 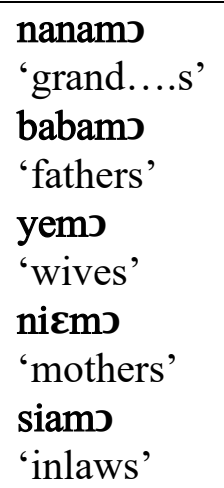 & \\
\hline Class 4 & & $(\mathrm{~V})-\_-n i \varepsilon /-\varnothing$ & N-_fue & Low \\
\hline$-n i \varepsilon / N-$ & -kremo & $\begin{array}{l}\text { kremonic } \\
\text { 'muslim' }\end{array}$ & $\begin{array}{l}\text { ygramofuc } \\
\text { 'muslims' }\end{array}$ & \\
\hline$-\varnothing / N-$ & -saman & $\begin{array}{l}\text { saman } \\
\text { 'ancestor' }\end{array}$ & 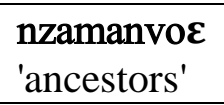 & \\
\hline Class 5 & & & & Low \\
\hline $\begin{array}{l}\text { Singularia } \\
\text { Tantum }\end{array}$ & & E-_-le & & \\
\hline $\begin{array}{l}\boldsymbol{a} . \\
\text { No plural }\end{array}$ & $\begin{array}{l}-s \varepsilon n \\
-h \supset I n\end{array}$ & 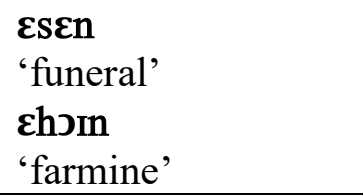 & & \\
\hline $\begin{array}{l}\boldsymbol{b} . \\
\boldsymbol{r} \varepsilon /- \\
\text { (deverbal) } \\
\text { No plural }\end{array}$ & $\begin{array}{l}\text {-wunze } \\
\text {-kuro } \\
\text {-dwudwo } \\
\text {-sirI }\end{array}$ & 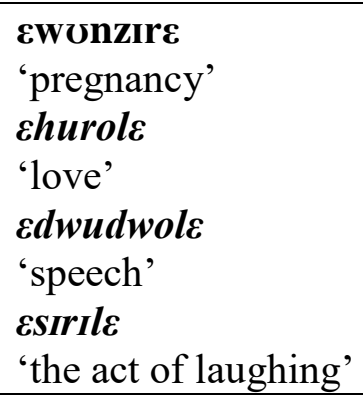 & & \\
\hline $\begin{array}{l}\text { c. } \\
\boldsymbol{\phi}_{-}-\boldsymbol{n} \varepsilon /- \\
\text { (derived }\end{array}$ & $\begin{array}{l}\text {-nzaa, } \\
\text { 'alcohol' - } \\
\text { nũ 'to } \\
\text { drink' }\end{array}$ & $\begin{array}{l}\text { nzaañ̃ne } \\
\text { 'alcoholism' }\end{array}$ & & \\
\hline
\end{tabular}




\begin{tabular}{|c|c|c|c|c|}
\hline $\begin{array}{l}\text { Compound } \\
\text { s) }\end{array}$ & $\begin{array}{l}\text {-sona } \\
\text { 'person', - } \\
\text { hũ 'kill' }\end{array}$ & $\begin{array}{l}\text { sonahũns } \\
\text { 'the act of } \\
\text { murdering' }\end{array}$ & & \\
\hline \multirow[t]{2}{*}{$\begin{array}{ll}\text { Class } & \text { 6: } \\
\text { Mass } & \\
\end{array}$} & & & & Low \\
\hline & & & $\begin{array}{c}\text { Pluralia } \\
\text { Tantum }\end{array}$ & \\
\hline \multirow[t]{2}{*}{ a. $\quad / N-$} & $\begin{array}{l}\text {-frama } \\
\text {-futro } \\
\text {-kyin } \\
\text {-gua }\end{array}$ & & $\begin{array}{l}\text { mvrama } \\
\text { 'air' } \\
\text { mvutro } \\
\text { 'dust' } \\
\text { ngyin } \\
\text { 'salt' } \\
\text { ygua } \\
\text { 'life' }\end{array}$ & \\
\hline & & Singularia tantum & & \\
\hline b. $\quad / V-$ & $\begin{array}{l}\text {-yia } \\
\text {-tẽẽn } \\
\text {-mo }\end{array}$ & $\begin{array}{l}\text { eyia } \\
\text { 'sun' } \\
\text { esraen } \\
\text { 'moon' } \\
\text { atẽẽn } \\
\text { 'roads' } \\
\text { عmo } \\
\text { 'rice' }\end{array}$ & & \\
\hline b. $\quad / \emptyset-$ & $\begin{array}{l}\text {-SIIn } \\
\text {-troo } \\
\text {-hãĩ } \\
\text {-wue }\end{array}$ & $\begin{array}{l}\text { sü } \\
\text { 'fire' } \\
\text { troo } \\
\text { 'soup' } \\
\text { hãĩ } \\
\text { 'light' } \\
\text { wue } \\
\text { 'honey' }\end{array}$ & & \\
\hline
\end{tabular}

As indicated earlier, morpho-phonological information enhances our understanding of the Esahie number-based classes, which are shown below. Data shown in the table were 
collected through elicitation from native speakers. In all a total of 120 nouns were collected, out 100 were chosen for the table for the convenience purposes. The table has five columns each spelling out some information about the noun such as its stem, productivity and noun class. Productivity of a class is determined based on two parameters: the number of nouns contained in $\mathrm{it}^{8}$, and the presence of neologisms ${ }^{9}$. On these grounds, three levels of productivity are distinguished, namely low, high and very high. In what follows, I provide a description of the classes shown in table 4.

\section{CLASS 1. $a \&$ \& $1 . b: V-/ N-$}

This class is common in Esahie. Plural formation in this class is easy even for the learner, because the pattern followed is very regular. Indeed, neologisms are integrated through the pattern observed in this class. ${ }^{10}$ In the singular, nouns in this class take a vowel prefix but take a (homorganic) nasal prefix in the plural. Nouns in Class 1 are instantiations of the morphological schema below:

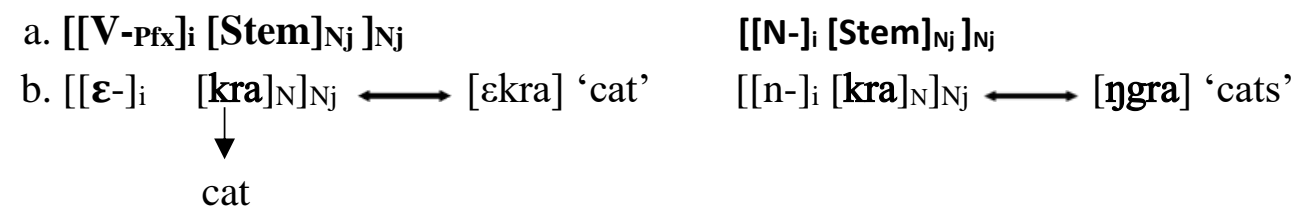

\section{Subclass 1.c: $\emptyset / \mathrm{N}-$}

This sub-class seems to contain the largest number of members and in fact constitutes the commonest and most productive in Esahie. The only difference with this sub-class is that nouns here in their singular are zero-marked. The loss or absence of the nominal prefix on the singular forms of nouns in this class is a strong indication of the morphological decay in this language. This decay is discussed in detail later in section 4.1.

The plural of nouns in this class are instantiations of the schema below, similar to the plural forms of class 1 which also take a (homorganic) nasal prefix.

\footnotetext{
${ }^{8}$ The average numerical strength of each class is used in setting out these levels. Out of the 100 tokens, any class that 30 and above tokens are considered as VERY HIGH, any class that contains 15 and above (but below 30) as classified HIGH, while groups that contains 15 tokens or below.

${ }^{9}$ Some of sources of the neologisms include student register and politics.

${ }^{10}$ For instance, gumu 'eating together by students in the hostel' takes the marker /n-/ in the plural to form "ygumu".
} 
(18) a. $\left[[\mathbf{N}-]_{i}[\text { Stem }]_{\mathrm{Nj}}\right]_{\mathrm{Nj}}$

$\left[[\mathrm{N}-]_{\mathrm{i}}[\text { braa }]_{\mathrm{N}}\right]_{\mathrm{Nj}}$

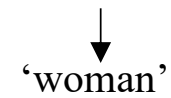

b. $\left[[\mathbf{N}-]_{i}[\text { Stem }]_{\mathbf{N j}}\right]_{\mathbf{N j}}$

$\left[[\mathrm{N}-]_{\mathrm{i}}[\mathrm{soa}]_{\mathrm{N}}\right]_{\mathrm{Nj}} \longrightarrow[$ nzoa] 'insults'

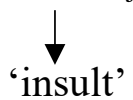

\section{CLASS $2(a):$ - $-/ A-$}

Members in this class take a vowel prefix in the singular and the prefix /a-/ in the plural. This class seems to have only a few members, and most of these appear to be borrowed from Akan. In the plural, members of this class are instantiations of the schema below:

\section{Singular}

a. $\left[[\varepsilon-]_{i}[\text { Stem }]_{N j}\right]_{N j}$

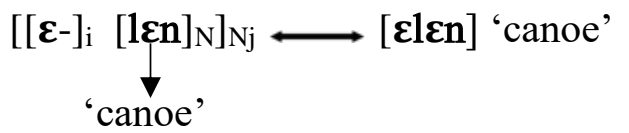

Plural

b. $\quad\left[[\mathbf{a}-]_{\mathrm{i}}[\mathrm{Stem}]_{\mathrm{Nj}}\right]_{\mathrm{Nj}}$

$\left[[\mathrm{a}-]_{\mathrm{i}}[1 \varepsilon n]_{\mathrm{N}}\right]_{\mathrm{Nj}} \longrightarrow[$ alen] 'canoes'

Members of sub-class 2.b are similar to those in Class 1, with a plural formation which follows the schema for forming plurals of Class 1 nouns. However, like Class 1 (c) nouns, their singular forms are a zero marked.

Members of sub-class 2.c appear to be 'double-edge' affixed in the plural. From a semantic perspective, we could analyse the items in this class here as 'identity' or 'occupational' nouns. This semantic information is derivative of the word formation phenomenon at work here, where the derivational affix consistently forms animate nouns from (inanimate) noun stems, with the meaning: 'person whose profession has to do with the noun base's referent'. Nouns in this class are instantiations of the schema below:

(20) Singular

a. $\left.\left[\left([\mathbf{a}]_{i}\right)[\operatorname{Stem}]_{\mathrm{N}_{j}}[-\mathbf{n i} \boldsymbol{k}]_{k}\right]\right]_{\mathrm{N}_{j}}$

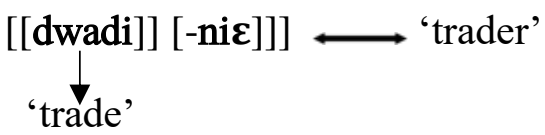

Plural

b. $\left.\left[[\mathbf{a}]_{i}[\text { Stem }]_{\mathrm{N}_{j}[}[\text {-for }]_{k}\right]\right]_{\mathrm{N}_{j}}$

[[a] [dwadi]] [-fuc] $\longrightarrow$ 'traders' 
As shown in (20a) above, in the singular, forms in this class may (not) take the prefix /a-/ and the derivative suffix $-\boldsymbol{n i \varepsilon}$, similar to the English derivative -er. It is noteworthy that while the English derivative -er mostly attaches to verb bases, the Esahie derivative -nic selects for nouns instead.

\section{CLASS 3: (V)-/(A)-_-mo}

Semantically, this class involves kinship nouns, and is one of the noun classes in Esahie that appears to have 'double-edge' affix positioning in the plural. This class of Esahie nouns can be sub-classified into two, obligatory or optional singular prefix marking in the singular. In the plural, however, nouns in the class always select the suffix $-\boldsymbol{m}$. They typically follow the schema in (21):

(21) a.

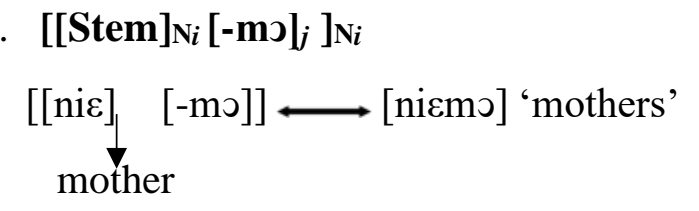

b. $\left[[\text { Stem }]_{\mathbf{N} i}[-\mathbf{m o l}]_{j}\right]_{\mathbf{N} i}$

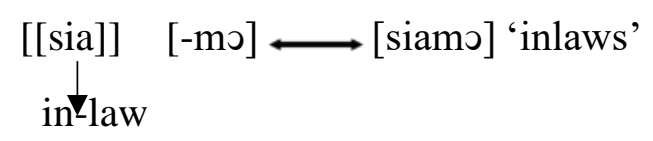

CLASS 4: $(-n i \varepsilon) / N-$ _ fo $\varepsilon$

Members of this class are similar to the noun forms in Class 3, except for the optionality of the suffix - niE and the homorganic nasal prefix attached in plural formation in this class. The schema below captures pluralization in this class:

$\left.\left[[\mathbf{N}-]_{i}[\text { Stem }]_{\mathbf{N}}[-\mathbf{f} \sigma \varepsilon]_{k}\right]\right]_{N j}$

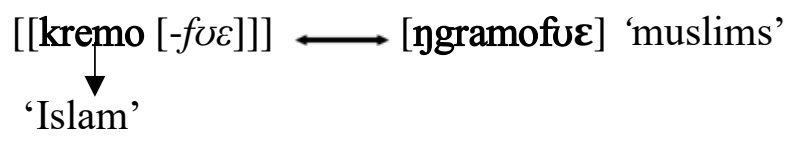

\section{CLASS 5: $\varepsilon--l \varepsilon$}

This class of Esahie noun forms do not mark the singular-plural distinction; i.e. it is a 'single-sided' class whose members only come in the singular (i.e. singularia tantum). Based on the fact that most of the nouns here are derived from a parent verb, and also that the prefix it selects is always used in the singular, this class is conceptually and morphosyntactically viewed as consisting of only singular forms. For instance, churole 'love' and

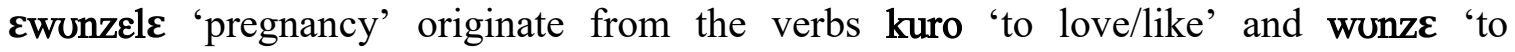


impregnate' respectively. The prefix / $\boldsymbol{\varepsilon}$-/ and the suffix /-l $\boldsymbol{\varepsilon} /$, which are used together in this class are usually derivational for the purpose of nominalization, ${ }^{11}$

\section{CLASS 6: / $N-, A-, \emptyset$ -}

This class contains one set of pluralia and two sets of singularia tantum respectively. However, the nouns here are not deverbal, contrasting with some of the noun forms in Class 5.

The pluralia tantum, triggering number agreement on the verb and other concord phenomena, are marked with a homorganic nasal, as most plurals in Esahie. The singularia tantum are like mass nouns, mostly triggering singular agreement in the syntactic context. Morphologically, they either take a vowel ([a- $]$ and $[\mathbf{e}-] /[\boldsymbol{\varepsilon}-])$ or surface as bare stems (zero affixation).

Having elaborated on the various singular-plural markers that exist in Esahie, as shown in table (4), we shall now pay attention to other morpho-syntactically relevant issues. More specifically, we shall consider issues bordering on morphological and morpho-syntactic decay in order to evaluate the morpho-syntactic strength of the Esahie NCS in general.

\subsection{Noun Class System in Esahie}

Although the noun class system in Esahie itself is syntactically inactive, number, as a syntactic feature, to some extent triggers agreement. First, we shall test the strength of the Esahie noun class system in the light of agreement marking. There are hardly distinct affixes that show up on nouns, nor morphological sets that mark agreement between nouns and their governing domain. The contrast with Tutrugbu (another G-T-M language, showing a syntactically active and rich system) is striking and points to the paucity of inflection marking in Esahie.

\section{Esahie}

(23) a. Baba ne wo awuro man DEF be.at home 'The man is at home'

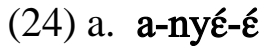
CM-man-DEF AM-be.at CM-house inside 'The man is at home'

${ }^{11}$ Both affixes here are derivational. 


\section{b. Mania ne-mo wo sua-n} People DEF-PL be.at house-inside 'The people are in the house' b. Ba-no ba-le bo-pa-m CM-person AM-be.at CM-house-inside 'The people are in the house'

(Essegbey 2009)

From the example (23), we notice that the Esahie rendition of the construction lacks any overt form of class and agreement marker. On the contrary, in the Tutrugbu ${ }^{12}$ version in (24a), $\boldsymbol{a}$ - is used to cross-reference the subject on the verb when it is singular. Similarly, in example (24b), Tutrugbu uses $\boldsymbol{b} \boldsymbol{a}$ - when it is plural in addition to the class marker, whilst Esahie shows no class nor agreement marker.

Esahie
Yamaa he te me-deos
rope this be 1.SG-POSS
'This rope is mine'
a. Kuku he te me-deos
pot this be 1SG-POSS
'This pot is mine'

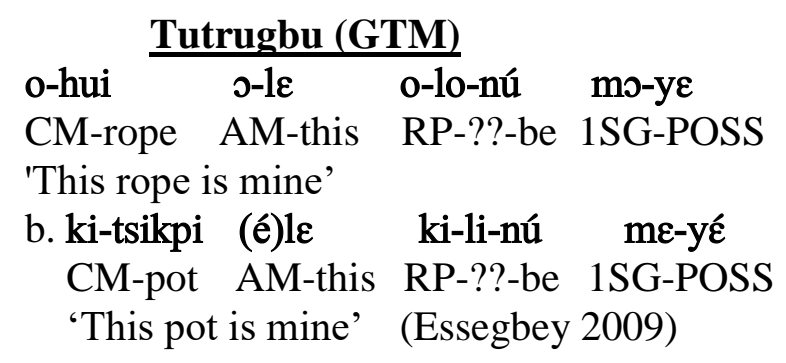

In the two Tutrugbu examples above, we observe that the nouns, the demonstratives and the verbs all bear class markers, agreement markers, and subject-verb agreement markers, respectively. What distinguishes the Esahie sentences, however, is their conspicuous lack of these class/agreement markings, both inside and outside the DP, in contrast with the case of Tutrugbu. The above observations corroborate the claim that noun classes in Esahie per se are morph-syntactically vestigial.

As Ameka (2008) rightly notes, there is an interesting split as far as plural formation and nominal classes are concerned in Kwa. In his explication, he shows that both Akan and its Tano relatives each have several pairs of singular and plural prefixes, and that while there is usually number concord, there is generally however, no class concord. He argues, for instance, that anaphors and modifiers of the languages within the Tano fraternity never show agreement with a head noun, while Ewe with the rest of Gbe and Ga-Dangme use the bare noun stem in the singular and a generalized suffix or clitic for the plural.

\footnotetext{
12 Though Essegbey (2009) argues that $\boldsymbol{a}$ - and $\boldsymbol{b} \boldsymbol{a}$ - are generalized agreement markers, the case of Esahie cannot be likened to it, because at least, in Tutrugbu these markers are overtly expressed.
} 


\subsubsection{Morphological Decay in Esahie}

\subsubsection{Loss of Singular Noun Prefixes}

One notable feature of the Esahie NCS is its morphological decay ${ }^{13}$ evidenced by the pervasive loss of noun prefixes in some singular nouns. Recall that in classes (1c) and (3b) in Table 4, we found a high number of nouns that were zero-marked in the singular. Recall that we mentioned earlier that the Akan NCS has also suffered some deal of morphological decay (cf. Osam 1993). In example (27), we compare the degree of this kind of morphological decay in Esahie and Akan.

\begin{tabular}{|c|c|c|}
\hline & $\underline{\text { Esahie }}$ & Akan \\
\hline$\underline{\text { Gloss }}$ & Singular & $\underline{\text { Singular }}$ \\
\hline Squirrel & pure & o-purow \\
\hline Dog & tcía & o-kraman \\
\hline Lady & brasua & o-baa \\
\hline Sheep & boaen & o-dwan \\
\hline
\end{tabular}

We notice that all the Esahie examples are zero-marked while their Akan counterparts are overtly marked.

\subsubsection{Frozen Nominal Forms}

Another piece of evidence that points to pervasive morphological decay in the Esahie NCS is the high incidence of frozen noun forms. Again, we shall compare Esahie with Akan in example (28) with respect to this phenomenon.

\begin{tabular}{|c|c|c|c|c|}
\hline \multirow[b]{2}{*}{ Gloss } & \multicolumn{2}{|c|}{ Esahie } & \multicolumn{2}{|c|}{$\underline{\text { Akan }}$} \\
\hline & Singular & Plural & Singular & Plural \\
\hline Building & sua & sua & $\varepsilon$-dan & a-dan \\
\hline Stone & nyəboe & nyoboe & e-boo & a-bos \\
\hline
\end{tabular}

\footnotetext{
${ }^{13}$ Although this work does not consider diachronic data (for purposes of unavailability of literature) in the discussion of this phenomenon of decay, a similar argument could be made for Esahie once we can establish that this phenomenon also obtains in other (sister) Kwa languages. For instance, inferences could be drawn from Akan, on which Osam (1993) establishes that, diachronically, there used to be a fully functional system.
} 


\begin{tabular}{|c|c|c|c|c|}
\hline Rope & yamaa & yamaa & \multicolumn{2}{|c|}{ a-homan-homa } \\
\hline Food & alie & 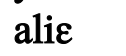 & a-duane & n-nuane \\
\hline Day & kyia & kyia & $\varepsilon$-da & n-na \\
\hline Farm & boo & boo & a-fuo & m-fuo \\
\hline Land & ase $\varepsilon$ & ase $\varepsilon$ & a-saase & n-saase \\
\hline Leaf & nyaa & nyaa & a-haban & n-haban \\
\hline
\end{tabular}

We observe that while all the Esahie examples maintain the same form in both singular and plural (i.e., they are syncretic ${ }^{14}$ ), the Akan equivalents are distinctively marked in both contexts.

\subsubsection{Morpho-syntactic Decay in Esahie}

The fact that the system in Esahie is a vestigial one is supported also by the morphosyntactic behaviour of nouns and their modifying adjectives. We shall first appeal to evidence from frozen adjectival forms, and proceed to look at this kind of decay beyond the scope of the DP.

\subsubsection{Frozen Form of Adjectival Prefixes}

In this section, we consider the form of adjectives when they modify singular and plural nouns.

$\begin{array}{ll}\text { Singular } & \underline{\text { Plural }} \\ \text { boaen bile } & \text { m-moaen bile } \\ \text { sheep black } & \text { PL-sheep black } \\ \text { 'Black sheep' } & \text { 'Black sheep' }\end{array}$

\begin{tabular}{|c|c|}
\hline$\underline{\text { Singular }}$ & Plural \\
\hline bia teq & $\mathrm{m}$-mia \\
\hline faulty & PL-chair \\
\hline 'Faulty chair' & 'Fau \\
\hline
\end{tabular}

From examples (29) and (30), we notice that the form of the modifying adjectives remains the same irrespective of the form of the head noun. In these examples, there is no nounadjective agreement.

\footnotetext{
${ }^{14}$ See Broohm and Rabanus (forthcoming) for a more detailed discussion.
} 


\subsubsection{Loss of Verbal Concord}

In this section, we consider the agreement between head nouns and verb, in order to ascertain whether the choice of a noun controls the selection or choice of the agreement marker on the verb.

$\begin{array}{lll}\text { a-ko } & \text { ne } & \text { ø-ko-wu } \\ \text { SG-fowl } & \text { DEF } & \text { AM-FUT-die } \\ \text { 'The fowl will die' } & \end{array}$
sua ne ø-ko-bu building DEF AM-FUT-break 'The building will collapse'

Unlike the Akan example in (10) which we saw earlier, where agreement markers (though not concordial in form), in the form pronominal clitics, were used to show agreement between the head noun and verb, in the Esahie examples (31) and (32), no such markers are found.

At this point, we shall return to our earlier argument that the Esahie NCS is numberbased one. Remember we have argued earlier that, while noun classes in Esahie by themselves are syntactically inactive, number (plural), as a syntactic feature, to some extent triggers agreement, despite the pervasive morpho-syntactic decay show.

In what follow, we shall take another look at number agreement in Esahie, limiting ourselves to what obtains in the DP, to find out whether there is still any special agreement (morphology) at all.

\section{Number Agreement in Esahie}

Number (plural) marking may occur on the head noun, nominal modifiers (such as adjectives), as well as demonstratives. In the examples that follow, we shall see how this works.

\section{(33) a. Bakaa hé stick DEM \\ 'This stick'}

b. m-makaa hé-m)
PL-stick DEM-PL
'These sticks'

In example (33a-b), we observe that both the head noun and the demonstrative agree in number, albeit using different markers. In the examples that follow we shall attempt to 
introduce other modifiers (demonstratives) into the DP, to be able to better appreciate how number concord generally works within the DP.

Singular (Ø-marked)
a. boaen tenden hé
sheep tall DEM
'This tall sheep'

a. bowie kwekwa kwekwa hene
bone dry RED
'That dry bone'

\section{Singular (V-marked)}
Plural (nasal-marked)
b. M-moaen n-denden he-mo
PL-sheep PL-tall DEM-PL
'These tall sheep'
b. m-mowie $\mathrm{n}$-kwekwa-kwekwa hene-mo PL-bone PL-dry-RED DEM-PL 'Those dry bones'
Plural (nasal-marked)
b. n-woo m-bri he-mo
PL-snake PL-big DEM-PL
'These big snakes'

In the examples (34b-35b) above, we observe agreement among the controller nouns, the modifying adjectives, the demonstratives. More importantly, we notice that while the demonstrative appears to invariably select $-\boldsymbol{m}$ o in the plural, irrespective of the form of marker borne by the head noun, the adjective, if it is marked, usually shares the same marker and marker distribution with the head noun (controller).

\section{Noun Classification and Gender: Esahie versus Akan}

As explained earlier, noun classification may manifest itself in the form a gender(like) system, where selection of markers is determined or controlled by certain inherent features (semantic, conceptual, and/or formal) of a lexical noun (controller) nouns.

In this section, we consider the inherent semantic feature of ANIMACY in Kwa languages, as akin to (grammatical) GENDER as attested in Romance languages (such as French and Italian). This implies that if the agreement system of a language shows strong sensitivity to the feature of animacy, that language would be analyzed as a gender-sensitive language. In what follows, we examine the extent to which inherent properties of Esahie nouns are crucial in our understanding of the Esahie agreement system. Again, we compare Esahie with Akan. 
For Akan, Osam (1996) shows that nouns are (to an extent) sensitive to the concept of ANIMACY. Thus, in some dialects, agreement could be triggered by the inherent conceptual and semantic feature of animacy. This animacy-based agreement system controls the selection/choice of nominal affixes for the various noun form classes (as shown in, Table 5), as well as the selection/choice of pronominal forms in agreement relations in Akan (as we shall see later).

Table 5: Animacy in Akan Noun Form Classes (based on Osam 1996: 154)

\begin{tabular}{|c|c|c|c|}
\hline Affix & $\begin{array}{c}\text { Semantic } \\
\text { feature }\end{array}$ & Example & Exceptions \\
\hline $0-/ 0-$ & ANIMATE & $\begin{array}{l}\text { o-panyin 'elder' } \\
\text { o-hoho 'visitor' } \\
\text { o-kodeع 'eagle' }\end{array}$ & Yes \\
\hline e-/ع- & INANIMATE & $\begin{array}{l}\text { e-boo 'stone' } \\
\text { e-dan 'house' } \\
\text { e-tuo 'gun' }\end{array}$ & No \\
\hline $\begin{array}{c}\text { Double plural } \\
\text { marked }\end{array}$ & +HUMAN & $\begin{array}{c}\text { a-hen-fo 'chiefs' } \\
\text { n-saman-fo 'ghosts' } \\
\text { m-banyin-fo 'men' } \\
\text { m-panyni-fo 'elders' }\end{array}$ & No \\
\hline
\end{tabular}

From the above, we observe that the role of animacy as (an inherent semantic feature) in the selection of nominal prefixes in Akan is one that cannot be overemphasized. The fact that two out of the three classes show no exception further buttresses the point. Let us now return to Esahie. 
Table 6: Animacy in the Esahie Noun Form Classes

\begin{tabular}{|c|c|c|c|}
\hline Affix & $\begin{array}{c}\text { Semantic } \\
\text { feature }\end{array}$ & Example & Exceptions \\
\hline e-/ $/ \varepsilon-$ & ANIMATE & $\begin{array}{c}\varepsilon \text {-kra 'cat' } \\
\text { e-woo 'snake' } \\
\text { e-bote 'rabbit' } \\
\varepsilon \text {-nwomee 'ghost' }\end{array}$ & Yes \\
\hline$-\mathrm{m}$ & $\begin{array}{c}\text { ANIMATE } \\
\text { (+KINSHIP) }\end{array}$ & ye-ms 'wives' & Yes \\
\hline $\begin{array}{c}\text { Double plural } \\
\text { marked }\end{array}$ & $\begin{array}{l}\text { ANIMATE } \\
\text { (+HUMAN) }\end{array}$ & 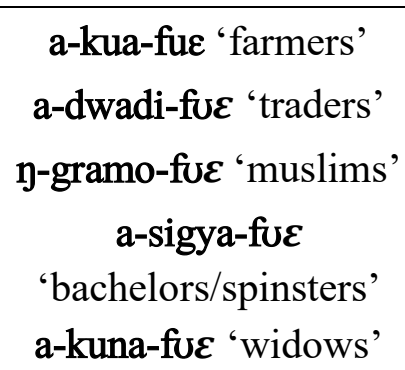 & Yes \\
\hline
\end{tabular}

Comparing Esahie to Akan, we observe that though animacy plays a role in the selection of nominal affixes, the existence of exceptions for each group of noun form classes, as shown in table 6 , gives an indication that the role of animacy is not very strong in Esahie, relatively speaking. What this means is that one could equally argue that the selection of such nominal affixes is arbitrary.

We shall now look at how the inherent/semantic feature of animacy manifests itself in the pronominal system in the context of agreement relations (anaphora agreement), again comparing Esahie with Akan (Twi). 
Akan

a. abofra no be-yera
Child the FUT-be.lost

'The child will get lost.' a.be-yera
AGR.ANIM-FUT-be.lost

'S/he will be lost.' b. Dua no be-yera

Tree the FUT-be.lost

'The tree will get lost.'

b. $\quad \varepsilon$-be-yera

(Osam 1996:157)

AGR.NONANIM-FUT-be.lost

'It will be lost.' (Osam 1996:158)

We notice that agreement pattern is reflected in the pronominal clitic on the verb in (38a) is triggered by the feature of animacy of the noun in (37a). A similar phenomenon is observed between (37b) and (38b). Juxtaposing both cases, we notice a distinction in the 3rd person pronoun paradigm with respect to animacy. We shall now return to Esahie to see whether or not same can be said for Esahie.

\section{Esahie}

a. adoma ne ko-muni baby the FUT-be.lost 'The baby will get lost.'

a. o-ko-muni

AGR.ANIM-FUT-be.lost 'S/he will be lost.' b. dadee ne ko-muni cutlass the FUT-be.lost 'The cutlass will get lost.'

b. o-ko-muni AGR.NONANIM-FUT-be.lost 'It will be lost.'

We observe from (39) and (40) that in Esahie, animacy, as an inherent semantic feature fails to trigger any kind of agreement. Instead, what obtains are cases of syncretism ${ }^{15}$ as the form of the pronominal clitic remains invariable despite the change in value of animacy feature.

\footnotetext{
${ }^{15}$ Broohm and Rabanus (forthcoming) deal extensively with this.
} 


\section{Conclusion}

As I hope to have shown, typologically, Esahie behaves just like her Central-Tano relatives such as Akan, wherein though noun classes themselves are syntactically inactive, number, as a syntactic feature still triggers concord to an extent. Comparing Esahie to Akan, the data discussed in this work point to the fact that Esahie has suffered a relatively stronger deal of morpho-syntactic decay in the nominal inflection system. The relatively pervasive loss of number (singular) markers, the higher incidence of frozen nominal forms, and the complete loss noun-verb agreement corroborate this point.

We could therefore conclude that, unlike Akan, there is no gender in the Esahie class system. Based on the data discussed in this work, the general typological picture of the Kwa NCS is depicted in the continuum shown in the diagram below.

\section{Morpho-syntactically Vibrant More conservative (G-T-M)}

GTM

\section{Morpho-syntactically vestigial Less conservative}

Central-Tano

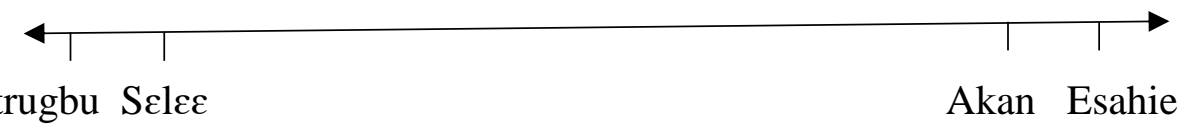

It has also been made clear that the role of semantic information in setting up nouns classes in Esahie is insignificant, noting rather that, nouns generally appear to be idiosyncratically assigned to one class or the other. In class 3, for instance, where class membership is triggered by a word formation rule, the role played by morpho-syntax interface is made evident. As argued for Akan (cf. Bodomo and Marfo, 2006), morphophonological information is equally relevant for understanding the choice of one number affix over the other in Esahie. Evidence from Esahie NCS, like that of many other African languages, provides grounds for grammatical interplay of various phonological, morphological, syntactic, and conceptual processes, as many theories suggest. 


\section{References}

Aboh, Enoch O, 2010. The morphosyntax of the noun phrase. In James Essegbey and Enoch. O. Aboh, eds., Topics in Kwa syntax New York: Springer. Pp. 11-37.

Aboh, Enoch O, and James Essegbey, 2010b. General properties of the clause. In James Essegbey and Enoch. O. Aboh, eds., Topics in Kwa syntax. New York: Springer. Pp. 39-64.

Agbetsoamedo, Yvonne, 2014. Aspects of the Grammar and Lexicon of Selec. Doctoral dissertation. Stockholm University. Sweden.

Ameka, Felix, and MEK, Dakubu, eds., 2008. Aspect and Modality in Kwa Languages. Amsterdam: John Benjamins.

Ameka, Felix, 2008. Aspect and modality in Ewe: a survey. In Felix Ameka, and MEK Dakubu, eds., Aspect and Modality in Kwa languages. Amsterdam: John Benjamins. Pp 135-194

Bobuafor, Mercy, 2009. Noun Classes in Tafi: A preliminary analysis. Utrecht: LOT.

Bodomo, Adam. \& Marfo, Charles, 2006. The Morphophonology of the Noun Classes in Dagaare and Akan. Studi Linguistici e Filologici. .Dipartimento di Linguistica, Universita di Pisa. http://www.humnet.unipi.it/slifo

Broohm. Obed Nii, \& Rabanus, Stefanus (Forthcoming). Agreement and Syncretism in Esahie.

Carstens, Vicky, 1991. The Morphology and Syntax of Determiner Phrases in Kiswahili. Los Angeles: University of California at Los Angeles. $\mathrm{PhD}$ dissertation.

Carstens, Vicky, 2008. DP in Bantu and Romance. In K. Demuth \& C. De Cat, (eds.). The Bantu-Romance Connection. Amsterdam: John Benjamins. Pp 131-166.

Creissels, D, 2000. Typology. In Bernd Heine \& Derek Nurse, eds., African Languages: An Introduction. Cambridge: Cambridge University Press. Pp 231-258. ,2014. Atlantic noun class systems: A typological approach. In Aicha Belkadi, Kakia Chatsiou and Kirsty Rowan eds., Proceedings of Conference on Language Documentation and Linguistic Theory 4. London: SOAS. www.hrelp.org/eprints/ldlt4_05.pdf

Crisma, P, Marten, L, and Sybesma, R, 2011. The point of Bantu, Chinese and Romance Nominal Classification. Rivista di Linguistica 23.2: pp. 251-299

Dolphyne, Florence A. and M. E. Kropp Dakubu, 1988. The Volta-Comoe Languages. In M. E. Kropp Dakubu (eds.), The Languages of Ghana. London: Kegan Paul International. Pp. $50-90$.

Dorvlo, Kofi, 2009. Noun class system and agreement patterns in Logba (Ikpana). LOT Occasional Series 13. Pp. $243-266$

Essegbey, James, 2009. Noun Classes in Tutrugbu. Journal of West African Languages. 
Pp 23-44

Frimpong, Victoria, 2009. Aspects of Esahie Phonology: An Autosegmetal Analysis. M. Phil thesis, University of Ghana. Accra.

Fiedler, Ines, 2016. Comparison of Gender across Kwa. Paper presented at the $2^{\text {nd }}$ Symposium on West African languages, held from $27^{\text {th }}-29^{\text {th }} 2016$, October at Vienna, Austria.

Heine, Bernd, 1982. African noun class systems. In H. Seiler and C. Lehmann. Apprehension: das sprachliche Erfassen on Gegenstanden, Tubingen: Narr. Pp 1134

Heine, Bernd, 2013. GTM noun class systems. How to deal with them in grammars? In GTM Workshop. Leiden.

Hendrikse, Andries Petrus, 2001. Systemic polysemy in the Southern Bantu noun class system. In Hubert Cuyckens \& Britta E. Zawada. Polysemy in Cognitive Linguistics. Pp 185-212.

Ikoro, S. M, 1996. The Kana Language. Leiden: Centre for Non-Western Studies.

Maho, Jouni, 1999. A Comparative Study of Bantu Noun Classes: Acta Universitatis Gothoburgensis. Gothenburg

Moxley, Jeri, 1998. Semantic structure of Bantu noun classes. In Maddieson Ian \& Thomas J. hinnebusch (eds.). Language History and Linguistic Description in Africa. Trends in African Linguistics 2. Trenton, NJ \& Asmara: Africa World Press, Inc. 229-238.

Ntumy, Samuel K. \& Ebenezer, Boafo, 2002. SIL Interaction. A summary report of African Studies. University of Ghana. Accra.

Osam, Kweku. E, 1993. The loss of the noun class system in Akan. Acta Linguistica Hafniensia Vol.17. Linguistics Circle of Copenhagen, 81-105. 1996. Animacy distinctions in Akan grammar. Studies in Linguistic Sciences 23.2. Pp 14 - 36

Palmer Gary B, \& Claudia Woodman, 2000. Ontological classifiers as polycentric categories, as seen in Shona class 3 nouns. In Lütz Martin \& Marjolijn H. verspoor, eds., Explorations in Linguistics Relativity. Amsterdam/Philadelphia: Benjamins. 225-249.

Sagna, Serge, 2008. Formal and Semantic Properties of the Gújjolaay Eegimaa (a.k.a. Banjal) Nominal Classification System. London: SOAS. PhD dissertation.

Schadeberg, Thilo C, 2001. Number in Swahili grammar. Afrikanistische Arbeitspapiere 68: Swahili Forum VIII. Pp 7-16.

Schuh, Russell G, 1995. Avatime noun classes and concord. Studies in African Linguistics 24 (2):123-148.

Selvik, Kari-Anne, 2001. When a dance resembles a tree: a polysemy analysis of three Setswana noun classes. In Cuyckens \& Zawada (2001). Pp 161-184. 
Broohm: Noun Classification in Esahie

Williamson, Kay \& Roger M. Blench, 2000. Niger-Congo. In Bernd Heine \& Derek Nurse (eds.), African Languages: An Introduction, Cambridge: Cambridge University Press. Pp 11-41. 